\title{
Reseña. Alejandro Sánchez Lopera. José Revueltas y Roberto Bolaño. Formas genéricas de la experiencia. Ed. A Contracorriente, 2017.
}

José Revueltas y Roberto Bolaño son autores cuyas obras, por lo general, están adheridas a acontecimientos históricos y literarios. Revueltas no sólo participó de las revueltas del 68 en México, su obra también podría leerse como una alegoría de ese momento. Bolaño vuelve con frecuencia al asunto del golpe militar en Chile en 1973 (como en Nocturno de Chile y Estrella distante) y al 68 mexicano en Amuleto (Bolaño vivió en México muchos años); y también se le reconoce como un revitalizador de la literatura latinoamericana post boom.

A Alejandro Sánchez Lopera no le interesa presentar un análisis de la obra de estos autores, sino que más bien encuentra en ellos campos de sentido lo suficientemente densos para generar especulaciones y acciones del pensamiento. El proyecto que nos presenta José Revueltas y Roberto Bolaño: formas genéricas de la experiencia es insertarse en el debate de qué representa o cómo se representa lo latinoamericano, pero no proveyendo una respuesta esencialista o basada en la identidad sino saliéndose en efecto del eje representativo para proponer una vía productiva. Sánchez Lopera investiga el texto, pero no lo hace para decir "esto es", sino para indicar -siguiendo de cerca al filósofo Giles Delueze- "he aquí un plano, por aquí se movilizan los signos". Latino América "es" la superficie por la que se 
desplaza el discurso, la imagen-tiempo ${ }^{1}$ que captura el acontecimiento, la materia viva de las fuerzas que componen el enunciado. Así, la acción que genera el crítico es transformar la obra de Revueltas y Bolaño en cajas de herramienta con las cuales construir aparatos de abordaje al presente para advertir de horrores que podrían aparecer ahora o en el futuro.

Sánchez Lopera, argumentando contra la tradición de Leopoldo Zea representada por Enrique Dussel, sostiene que la obra de Revueltas permite entender Latino América no como una identidad (buscada o hallada) ni como un territorio (encubierto o depredado) sino como una isla siempre transformándose, una "imagen-tiempo". Esta noción, extraída también de Deleuze, se deriva a su vez de la perspectiva cinematográfica del mundo que Sánchez Lopera destila de la vida y obra de Revueltas. Revueltas madura como escritor cuando la estética fílmica se había asentado en el mundo, su mirada intelectual es mediada por la sucesión de imágenes del film.

Sánchez Lopera lleva a cabo la siguiente extrapolación para proponer así una hipótesis sobre la relación entre la mente y las percepciones: con Revueltas es posible construir pensamiento ya que al igual que la imagen cinematográfica la mente está compuesta de "superposiciones, combinaciones y discontinuidades". (47) Al leer a Revueltas el lector no deriva "México es esto o es aquello" o "la revuelta del 68 significó esto o aquello", sino que esa circunstancia y ese acontecimiento son planos por los que se mueven las acciones, y, por extensión, la lectura es la actividad del lector en esos planos. Este discurso crítico implica una postura ético-política, la lectura de Revueltas podría redundar en mayor participación en el presente.

Una imagen impregnada de tiempo no es lo mismo que una imagen a secas. Escribir como quien busca hacer del pensamiento imagen del mundo para montar esa instantánea en el río del tiempo. Así escritura e imagen se vuelven mundo, nunca cesan de producirse, nunca cesan de cambiar.

1 Una imagen-tiempo es una imagen que está saturada de tiempo. Deleuze reconoce tres: reconocimiento, rememoración y sueño. 
Elaborando sobre la novela de Revueltas Los errores, Sánchez Lopera sostiene "La verdad no está entonces ligada al ser, sino que es un conjunto creciente de perspectivas" (52) Al igual que el cine, Latino América es pensamiento sucesivo, multiplicidad de imágenes todas válidas, perspectivas que resisten la singularidad de la representación. Latino América visibiliza la complejidad pero no la significa; no es un mapa, es un grid en el que se pueden trazar figuras y trayectos.

Sánchez Lopera se vale de la obra de Roberto Bolaño para insertar la preocupación y el problema de la memoria en el aparato filosófico que construyó con Revueltas. La mirada cinematográfica está instalada también en la obra de Bolaño -las imágenes se suceden en los textos como si fueran fragmentos de verdad-, pero una pregunta se añade a la lectura crítica, ¿cómo opera el olvido bajo condiciones neoliberales? Entiendo por neoliberal aquella persona que no desea que los gobiernos pongan trabas en la extracción de la mano de obra y de los bienes en la producción de riqueza para un grupo ínfimo de los ciudadanos.

Para el crítico, en Bolaño "la memoria es una fuerza, algo que conmueve el estado de las cosas por una intromisión del porvenir". (144) Ser "memorioso" es aceptar la condición en devenir de las cosas en el mundo, saber que, si el neoliberalismo es la doctrina capitalista que ve en la preservación de los recursos un estorbo, la memoria es la energía del futuro para potenciar las acciones para detener ese avance. Hay que recordar aquí la noción de Giorgio Agamben del humano como un ser en potencia y de potencia. Ser en potencia es que todavía no está en efecto actuando y por supuesto conserva la posibilidad de no actuar; ser de potencia es aquello que se vierte al futuro reconociendo la transformación como un componente da la travesía por la Tierra. "La vida debe ser pensada como una potencia que incesantemente excede sus formas y sus realizaciones ${ }^{2}$."

La literatura también es una herramienta para la resistencia. Tanto Revueltas como Bolaño, en esta lectura, son escritores “comprometidos", estrategas políticos en la trinchera del enunciado. [Con]prometidos, que albergan en sí el fuego de la

\footnotetext{
${ }^{2}$ Giorgio Agamben. La potencia del pensamiento. Barcelona: Anagrama, 2008. 299
} 
promesa. Escritores utópicos, pero no en el sentido convencional que ese término implica, mezcla de idealismo con escapismo (en su acepción negativa); sino utopía como fuera-de-lugar, o, mejor, auscultadores de ese lugar que los dueños del mundo han diseñado como utopía para descartar el pensamiento de los "soñadores", escritores desencajados, out of joint para usar la terminología de Philip K. Dick.

Bolaño indica para la historia de la literatura latinoamericana una corroboración de la materia dura de los eventos que componen los textos literarios: la historia latinoamericana es también la historia del dolor, pero este reconocimiento no está enunciado desde el lamento, la queja o la pena. Antes bien es la política como felicidad, el estar en el mundo con la mente y la mirada clara. A Bolaño le interesa comprobar que escribir es una puesta en juego entre el evento y la memoria. La protagonista de Amuleto -relato sobre el 68 mexicano- no indaga el pasado, ni siquiera lo documenta en vivo, sino que interroga el presente y el futuro. Bolaño no es el escritor de "prohibido olvidar", es más bien el escritor que anuncia que el acto de recordar es poner en función la posibilidad de que el horror podría volver a suceder en cualquier momento: recordar es la acción de la conciencia vertida al futuro.

Para la protagonista de Amuleto - a quien el crítico compara con Funes el memorioso de Jorge Luis Borges- todo está mezclado, todos los eventos no tienen tiempo propio. Como si los eventos transitaran por una especie de continuum temporal y ocasionalmente descendieran como gotas en lugares aleatorios del continuum espacial. El 68 descendió del tiempo en ese momento pero podría descender hoy o en 25 años. No se debe prestar atención a la ciencia ficción pop ${ }^{3}$ que se oculta en el argumento, más bien esa hipótesis crítica permite retomar la noción de [con]promiso como especulación out of joint. Los desencajados son los que están alertas a las gotas de horror que pueden caer del continuum.

${ }^{3}$ Las dislocaciones espacio-temporales son un lugar común en la literatura de ciencia ficción que versa sobre el tema de viajes en el tiempo. El trato light es algo que percibo en el argumento crítico, pero se debe recordar que Bolaño fue un entusiasta lector de Dick. 
El texto exhibe un considerable número de errores editoriales y de formato; aunque notables y penosos no utilizaré esta reseña para enumerarlos o comentarlos. Lo que sí anoto es que, así como Alejandro se dispuso a "pensar con Revueltas y Bolaño", de mi lectura de su texto una noción del pensamiento emerge. Pensar es estar en el mundo, ocurre en el mundo, cuando pienso estoy en el mundo y el mundo está en mí. No hay afuera ni adentro, la mota de nieve cae ahora mismo en Pittsburgh y la veo por la ventana, se posa en el suelo y se congrega con sus otras hermanas en la danza gélida de los cuerpos del suelo: abordaje, engranaje, disolución, proliferación. 